\title{
Estimation of Particle Material And Dissolved Flows During Floods In The Inaouene Watershed. (Northeast Of Morocco)
}

\author{
Hayat Sibari ${ }^{1 *}$, Souad Haida ${ }^{1}$ and Mohamed Foutlane ${ }^{2}$ \\ 1. Laboratory: Geoscience and Naturel Ressources, Departement of Geology, Faculty of Science. \\ Ibn Tofail Uninersity, Maamora Campus, Morocco.
}

2. National Office of Potable Water (ONEP), 6 Avenue Oued Akrach, 10000, Rabat. Morocco.

\begin{abstract}
This work aims to estimate the contributions of the Inaouene River during the floods. It is in this context that the dissolved and particulate matter flows were measured during the flood periods followed by the 1996/97 study year at the two hydrological stations Bab Marzouka (upstream) and El Kouchat (downstream). The specific flows of dissolved materials calculated upstream and downstream of the Inaouene watershed correspond respectively to $257 \mathrm{t} / \mathrm{km}^{2} /$ year and $117 \mathrm{t} / \mathrm{km}^{2} /$ year. Chlorides represent $30 \%$ and $41 \%$ respectively of the total dissolved transport upstream and downstream. The potential mechanical degradation affecting the Inaouene watershed can deliver a solid load estimated at $6.10^{6} \mathrm{t} /$ year corresponding to a specific flow of $2142 \mathrm{t} / \mathrm{km}^{2} /$ year.
\end{abstract}

Key words: Inaouene, watershed, Floods, Material flow, Specific flow, Morocco.

\section{Introduction}

The work we put forward about the Inaouene watershed relates to the Moroccan programs that aim at preventing and limiting the degradation of natural ecosystems as well as protecting dams' retention mainly in the Northern region of the country. The purpose of the present work then is to establish a quantification of flow solid matter dissolved and carried away at the level of this watershed during floods and also to study the relationships between these flows and the intake liquids.

The Inaouene watershed occupies an eastern position in the sebou watershed (fig. 1), between the last Middle Atlas foothills and the pre-Rif sector. It covers an area of 3322 $\mathrm{km}^{2}$. The Inaouene River, second main tributary of the Sebou River after Ouergha, flows in an East-West direction, along the South-Rif corridor. The Inaouene receives the flows of the tributaries, on its right bank, which collect the runoffs of the Prerif hills and the flows of the tributaries, on its left bank, fed partly by the primary block of Tazekka, but especially by the limes of the Middle Atlas, often karstic in this region. The Sebou 
watershed is largely influenced by the Atlantic climate, whereas the Inaouene belongs to the western climate fringe of a Mediterranean climate with oceanic influence.

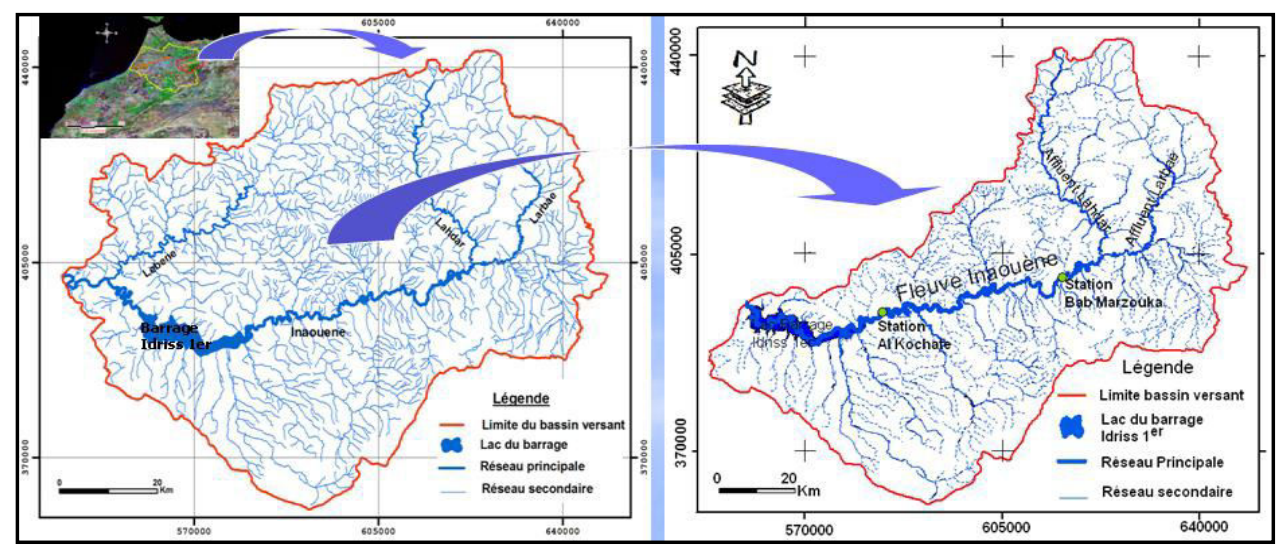

Figure.1 : map of the geographic location of the Inaouene watershed

\section{Materials and methods}

As part of this study, we carried out a sampling campaign at two hydrological stations: Bab Marzouka and El Kouchat situated respectively upstream and downstream of the Inaouène watershed. This sampling was carried out during the 1996/97 hydrological year on the basis of to two different frequencies: one weekly and the other daily during floods.

Samples have been taken approximately 1 meter deep. The collected water is placed in polyethylene bottles carefully washed with $10 \%$ nitric acid. These samples were filtered on a Millipore filter at $45 \mu \mathrm{m}$ and the contents of suspended solids were measured by weighing the filters taken back (reported) to the volume of filtration water. As water samples were taken, water level readings were taken at the gauging stations, and using the calibration curves established by the DRPE (Research and Planing of Water Management), these water levels were transformed and corrected into liquid flows. During floods, only the water samples corresponding to the February 1997 flood upstream and downstream of the Inaouène were subjected to physicochemical analyzes (ONEP) to determine the behavior of certain major chemical elements during this period of flow. Table 1 shows the flowing volume, the liquid flow of the period during which the flood was sampled and the peak flow for each flood.

Table 1 : Sampling Périod, volume water flow and the peak flow for February of Inaouene (hydrologic cycle studied in 1996/97).

\begin{tabular}{|c|c|c|c|c|c|}
\hline Station & Beginning & End & $\begin{array}{c}\text { Volume } \\
\left(\mathrm{Mm}^{3}\right)\end{array}$ & $\begin{array}{c}\text { specific liquid flow } \\
\left(1 / \mathrm{s} / \mathrm{km}^{2}\right)\end{array}$ & peak flow $\left(\mathrm{m}^{3} / \mathrm{s}\right)$ \\
\hline $\begin{array}{c}\text { El } \\
\text { Kouchat }\end{array}$ & $13 / 02 / 97$ & $22 / 02 / 97$ & 2820 & 31,94 & 167 \\
\hline $\begin{array}{c}\text { Bab } \\
\text { Marzouka }\end{array}$ & $10 / 02 / 97$ & $19 / 02 / 97$ & 1696 & 35,86 & 109 \\
\hline
\end{tabular}


The calculation methods of matter flow in water streams have already been dealt with by several authors such as $[2,3,7,10,11]$. In this case, the calculations have been achieved through the stochastic method that has already been applied to other watersheds in semi-arid areas: Tensift $[4,5]$ and Sebou [6]. This method makes it possible to calculate for each period (i), the average of the concentrations (Cim) weighed by the liquid flow rates. The matter flow (Fi) would be the product of this concentration (Cim) in the volume of water (Qi) obtained by integrating the flows for the period (i).

$$
\operatorname{Cim}=1 / \sum_{i=1}^{n} Q i \times \sum_{i=1}^{n} C i \times Q i \quad ; \quad F i=\sum_{i=1}^{n}\left(\operatorname{Cim} \times \int_{t 1}^{t 2} Q d t\right)
$$

\section{Results and discussion}

\section{1. solid Flows}

\subsubsection{Changes in the SS rate during floods}

The rate of suspended solids generally follows the variations of the liquid flow rates. There are five main SS export periods corresponding to five flood episodes observed between December 1996 and February 1997. Of these five episodes, we observe a certain proportionality between the intensity of the flood peaks. and those of suspended solids peaks. The most important flood is that of February with a maximum flow of 167 $\mathrm{m}^{3} / \mathrm{s}\left(59.641 / \mathrm{s} / \mathrm{km}^{2}\right)$ at El Kouchat and $109 \mathrm{~m}^{3} / \mathrm{s}\left(72.661 / \mathrm{s} / \mathrm{km}^{2}\right)$ at Bab Marzouka and suspended matter contents of $30 \mathrm{~g} / 1$ at El Kouchat and $24 \mathrm{~g} / 1$ at Bab Marzouka (Fig. 2).

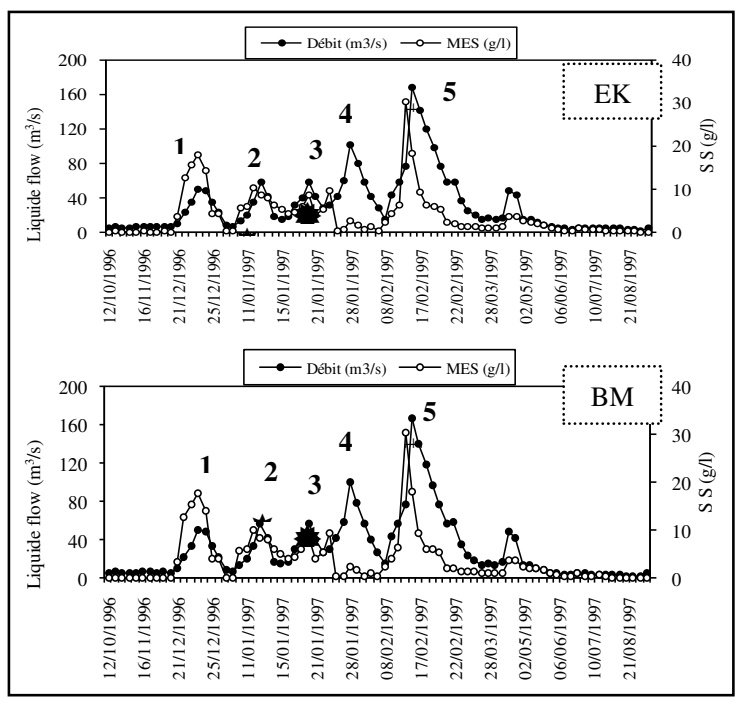

Figure 2 : Evolution of instantaneous flow rates and SS concentrations measured in the waters of Inaouène at El Kouchat (EK) and Bab Marzouka $(\mathrm{BM})(1,2,3,4$ and 5 are the main floods sampled). 
In times of high water, where the transport power increases, the contents of suspended solids are very important reaching respectively upstream and downstream $10.52 \mathrm{~g} / 1$ and $6.63 \mathrm{~g} / \mathrm{l}$. The highest levels of suspended matter recorded are mainly due to the mechanical erosion that predominates in the Prerif.

\subsubsection{Comparison of solid flows between upstream and downstream basin}

Table. 2 shows the characteristics of each of the floods monitored and the calculated tonnage values of the matter exported in suspension. The flows of solid matter transported by Inaouéne upstream and downstream are respectively $4.8910^{6}$ tonnes and 6. $10^{6}$ tonnes. The specific degradation corresponding to the upstream basin of an area of $1500 \mathrm{~km}^{2}$ is $3260 \mathrm{t} / \mathrm{km}^{2}$ / year and that downstream for an area of $2800 \mathrm{~km}^{2}$ is $2141 \mathrm{t}$ / $\mathrm{km}^{2} /$ year.

As several studies have shown, erosion is a catacyclismic phenomenon, which means that most of the suspended matter is removed during a few floods $[1,2,8,9]$. Indeed, all the major floods that occurred during the three months of the study year (December to February) are responsible for 71 to $75 \%$ of annual solid transport.

Table 2: Comparative contribution of the flood episodes to the total tonnage of suspended matter exported by Inaouène

\begin{tabular}{|l|l|l|l|l|l|l|l|l|}
\hline \multicolumn{2}{|c|}{} & $\begin{array}{l}\text { Annual } \\
\text { Total }\end{array}$ & $\begin{array}{l}\text { flood } \\
1\end{array}$ & $\begin{array}{l}\text { flood } \\
2\end{array}$ & $\begin{array}{l}\text { flood } \\
3\end{array}$ & $\begin{array}{l}\text { flood } \\
4\end{array}$ & $\begin{array}{l}\text { flood } \\
5\end{array}$ & $\begin{array}{l}\text { Total } \\
\text { flood }\end{array}$ \\
\hline Bab Marzouka & $\begin{array}{l}\text { period } \\
\text { (days) }\end{array}$ & 365 & 7 & 4 & 5 & 6 & 10 & 32 \\
\cline { 2 - 10 } & $\begin{array}{l}\text { Tonnage } \\
10^{6} \mathrm{~T}\end{array}$ & 6,88 & 0,51 & 0,40 & 0,35 & 0,83 & 2,80 & $\mathbf{4 , 8 9}$ \\
\cline { 2 - 10 } & $\%$ year & 100 & 7 & 6 & 5 & 12 & 41 & 71 \\
\hline \multirow{5}{*}{ El Kouchat } & $\begin{array}{l}\text { period } \\
\text { (days) }\end{array}$ & 365 & 6 & 6 & 5 & 6 & 8 & 31 \\
\cline { 2 - 10 } & $\begin{array}{l}\text { Tonnage } \\
10^{6} \mathrm{~T}\end{array}$ & 8,03 & 0,79 & 0,70 & 0,42 & 0,13 & 3,95 & $\mathbf{5 , 9 9}$ \\
\cline { 2 - 10 } & $\%$ year & 100 & 10 & 9 & 5 & 2 & 49 & 75 \\
\hline
\end{tabular}

\subsection{Dissolved flows}

\subsubsection{Variations of instantaneous flows during floods}

The variations of the instantaneous upstream and downstream flows are shown in Figure 3. The highest dissolved loads are those of chlorides, sodium and bicarbonates. In terms of instantaneous flux, these variations show the importance of the contribution of upstream slopes in the export of chlorides and the contribution of downstream carbonate slopes in the export of bicarbonates. 


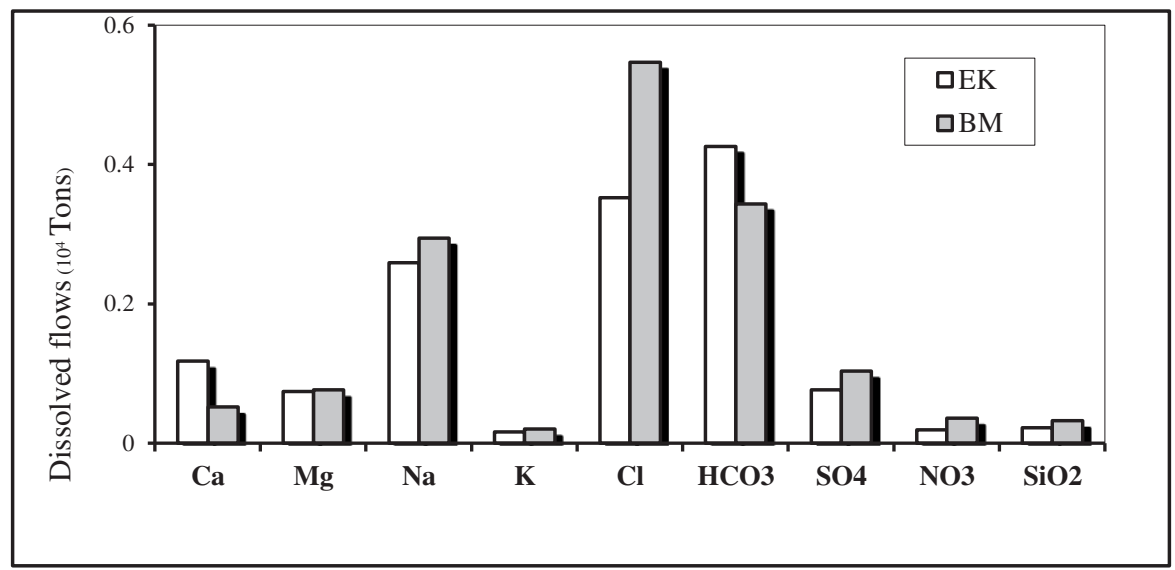

Figure 3: Average flows of major elements in Inaouene waters at the Bab Marzouka (BM) and El Kouchat (EK) stations during the February 1997 flood.

\subsubsection{Dissolved flow relationship - liquid supply}

Flows - liquid supply relationships show higher flows during the first flood rise than during the rest of the flood. This indicates that from the onset of the flood, rainwater and surface water strongly dragged away the elements that are highly concentrated in the soil surface horizons. The flows of the different chemical elements of Inaouene waters generally have highly significant linear relationships with liquid inputs (Fig.4).
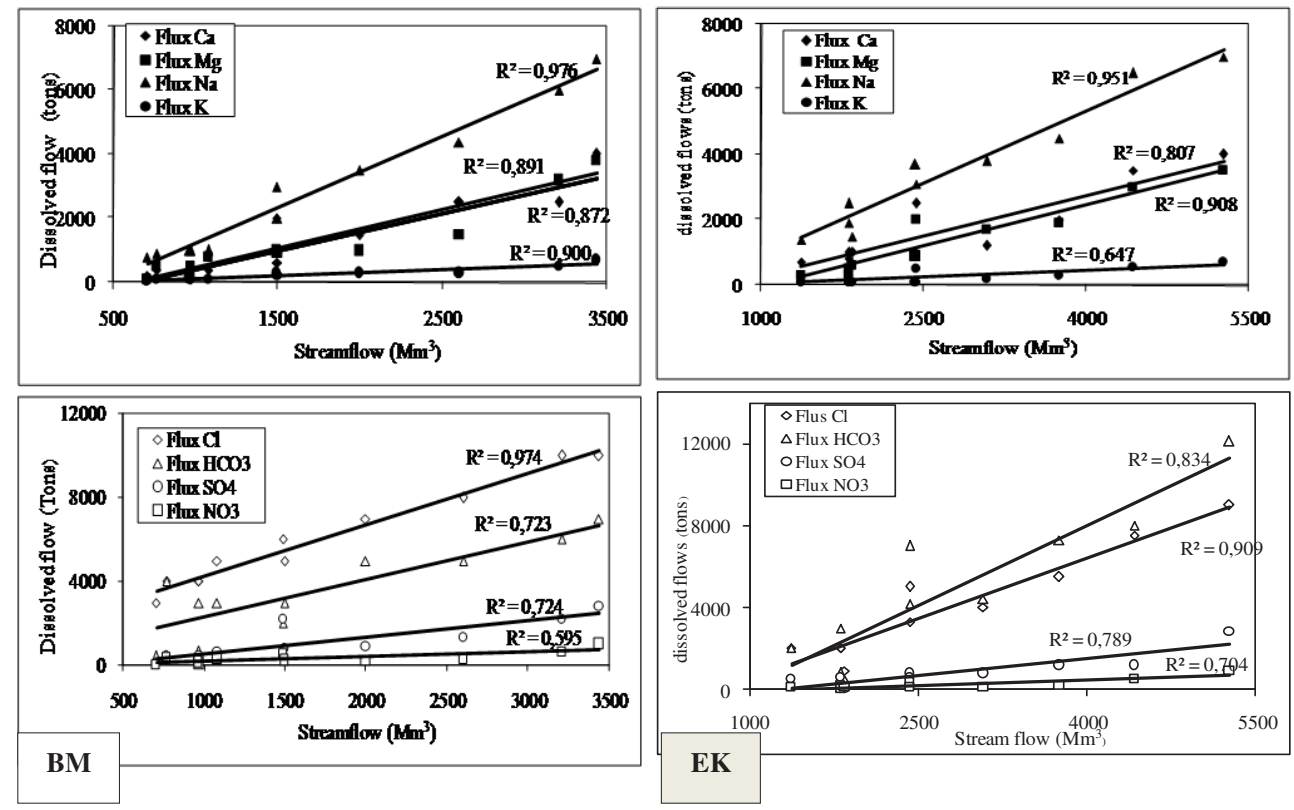
Figure 4: Relationship between the instantaneous fluxes of the major dissolved elements and the liquid inputs of the Inaouene waters to Bab Marzouka (BM) and El Kouchat (EK) during the February 1997 flood.

These relationships depend on the initial water conditions of the basin and seasonal variations. In fact, during floods following dry initial water conditions, the dissolved flows are more or less high during the rise phase of the flood due to the intense leaching of the soil surface horizons by the rainwater and by the superficial waters.

These dissolved flow - liquid supply relationships show that the different types of flow, the superficial flow and the deep flow, participate in the genesis of flows and intervene in different proportions. During the flood phase, the participation of the surface flow is greater than in the second flood phase. This flow thus causes a dilution of the deep flow rich in alteration product $(\mathrm{Cl}$ and $\mathrm{Na})$ which participate in dominant proportions.

\subsubsection{Comparison of hydrochemical flows between upstream and downstream basin}

During this cycle, Inaouene exported an average of $33.10^{4}$ tons $\left(117 \mathrm{t} / \mathrm{km}^{2} /\right.$ year $)$ of major chemical elements in solution. Chloride inputs downstream are about $9.610^{4}$ tons, or $29.5 \%$ of total solution transport. The tonnages of bicarbonates, sodium and sulphates respectively represent $26 \%, 23 \%$ and $7 \%$ of the total dissolved flow. Upstream of the basin, the tonnage of the various elements in solution is on average $38.10^{4}$ tons $(257 \mathrm{t} /$ $\mathrm{km}^{2} /$ year) (Tab.3).

Table 3: Comparison of hydrochemical flows between upstream and downstream of the Inaouene basin

\begin{tabular}{|l|c|c|c|c|c|}
\hline \multicolumn{3}{|c|}{ Inaouène in El Kouchat } & \multicolumn{3}{c|}{ Inaouène in Bab Marzouka } \\
\hline kind & $\begin{array}{l}\text { Annual } \\
\text { Tonnage } \\
\left(10^{4} \text { tons }\right)\end{array}$ & $\begin{array}{l}\text { Relative } \\
\text { Contribution } \\
(\%)\end{array}$ & kind & $\begin{array}{l}\text { Annual } \\
\text { Tonnage } \\
\left(10^{4} \text { tons }\right.\end{array}$ & $\begin{array}{l}\text { Relative } \\
\text { Contribution } \\
(\%)\end{array}$ \\
\hline $\mathrm{Ca}^{2+}$ & 2,20 & 6,7 & $\mathrm{Ca}^{2+}$ & 1,58 & 4,1 \\
$\mathrm{Na}^{+}$ & 7,73 & 23,6 & $\mathrm{Na}^{+}$ & 8,38 & 21,7 \\
$\mathrm{Mg}^{2+}$ & 1,30 & 4,0 & $\mathrm{Mg}^{2+}$ & 1,29 & 3,3 \\
$\mathrm{~K}^{+}$ & 0,30 & 0,9 & $\mathrm{~K}^{+}$ & 0,63 & 1,6 \\
$\mathrm{HCO}_{3}^{-}$ & 8,50 & 26,0 & $\mathrm{HCO}_{3}^{-}$ & 8,15 & 21,1 \\
$\mathrm{Cl}^{-}$ & 9,60 & 29,5 & $\mathrm{Cl}^{-}$ & 16,16 & 41,9 \\
$\mathrm{SO}_{4}{ }^{2-}$ & 2,50 & 7,6 & $\mathrm{SO}_{4}^{2-}$ & 1,38 & 3,6 \\
$\mathrm{NO}_{3}^{-}$ & 0,33 & 1,0 & $\mathrm{NO}_{3}^{-}$ & 0,47 & 1,3 \\
\hline $\mathrm{SiO}_{2}$ & 0,25 & 0,7 & $\mathrm{SiO}_{2}$ & 0,54 & 1,4 \\
\hline $\mathrm{Total}^{-}$ & 32,71 & $100 \%$ & $\mathrm{Total}^{-}$ & 38,58 & $100 \%$ \\
\hline
\end{tabular}

\section{Conclusion}

This study has highlighted the importance of floods in the dynamics and transport of solid and dissolved matter in the Inaouene watershed. During the 1996/97 hydrological 
cycle, the dissolved flux measured downstream from the Inaouene River averaged $33.10^{4} \mathrm{t} /$ year. Chlorides, sodium and bicarbonates correspond to the bulk of this dissolved load, thus denoting the contribution of the evaporiferous pre-crystalline formations and the carbonate formations of the Middle Atlas. The potential mechanical degradation affecting the basin can deliver a solid load estimated at $610^{6} \mathrm{t} /$ year corresponding to a strong mechanical erosion $\left(2141 \mathrm{t} / \mathrm{km}^{2} /\right.$ year). Compared to global solid flows, it is of equal magnitude as those of the Asian Hunghe River and the Colombian River Magdalena. The high intensity of the mechanical erosion revealed by the Inaouene is due particularly to the nature of the lithological formations, the climatic irregularity and the weakness of the vegetal cover favoring the erosive action of the rainwater which is generally very brutal and of short duration.

\section{Références}

1. I. DOUGLAS I: Intensity and periodicity in denudation processes with special reference of Turkey. J. of Hydrol., 14, 233-258 (1964).

2. D. ETCHANCHU : Géochimie des eaux du bassin de la Garonne. Transfert de matières dissoutes et particulaires vers l'océan Atlantique. Thèse $3^{\mathrm{e}}$ cycle, Toulouse, $156 \mathrm{p}$ (1988).

3. R.I. FURGUSON: Accuracy and precision of methods for estimating river loads. Earth surface processes and landformes, $n^{\circ} \mathbf{1 2}, 95-104$ (1987).

4. S. HAIDA : Flux de matières issues de zone semi-aride le bassin versant de l'oued Tensift (Maroc). Estimation quantitative et qualitative: bilan. Thèse $3^{\text {eme }}$ cycle, Université. Mohamed V, Faculté des Sciences. Rabat, Maroc, 147p (1991).

5. S. HAIDA., M. SNOUSSI.,C. LATOUCHE et J.L. PPRBST : Géodynamique actuelle du bassin versant de l'oued Tensift (Maroc) : Erosion et bilan des transports solides fluviaux. Bulletin des Sciences Géologiques., Strasbourg, 49, 1-4, p. 7-23 (1996).

6. S. HAIDA. : Transports de matières et bilans de 1 'érosion mécanique et de l'altération chimique sur le bassin versant de zone semi-aride: le Sebou. Thèse doctorat EsSciences, Université Ibn Tofail, Faculté des Sciences. Kénitra, Maroc, 253p (2000).

7. Z. KATTAN : Géochimie et hydrologie des eaux fluviales des bassins de la Moselle et de la Mossig, Transports dissous et particulaires, cycles biogéochimiques des éléments. Thèse, Université Louis Pasteur de Strasbourg., 167p (1989).

8. Z. KATTAN et J .L. PROBST : Transports en suspension et solution par la Moselle en périodes de crues. Actes Journées d'Hydrologie «Crues et Inondations », Strasbourg, 16-18 Octobre. 143-167 (1986).

9. J.L. PROBST : Géochimie et hydrologie de l'érosion continentale. Mécanismes, bilan global actuel et fluctuations au cours des 500 derniers Millions d'années. Sc. Géol, 94, $161 p$ (1990).

10. J.L. PROBST, R. NKOUNKOU, G. KREMPP, J.P., J.P. THIBEAUX etJ.C. OLIVRY: Dissolved major elements exported by the Gongo and Ubangui revers during the period 1987-1989. J. Hydrol. 135,237-257 (1992).

11. J.L. PROBST et Y. TARDY: Long range streamflow and world continental runoff fluctuations since the beginning of this century. J. of Hydrology, $\mathrm{n}^{\circ} \mathbf{9 4}, 289-311(1987)$. 